\title{
Toxicity and repellency of essential oils in the management of Sitophilus zeamais
}

\author{
Alice M. N. de Araújoํㅜㄹ José V. de Oliveira ${ }^{1}$, Solange M. França ${ }^{2}$, \\ Daniela M. do A. F. Navarro ${ }^{3}$, Douglas R. e S. Barbosa ${ }^{1} \&$ Kamilla de A. Dutra $^{3}$ \\ ${ }^{1}$ Universidade Federal Rural de Pernambuco/Departamento de Agronomia. Recife, PE, Brasil. E-mail: alicemna@yahoo.com.br - ORCID: 0000-0002- \\ 7519-9865; joseoliveiravargas@gmail.com - ORCID: 0000-0001-6976-6504; douglas.barbosa@ifma.edu.br - ORCID: 0000-0003-0234-773X \\ ${ }^{2}$ Universidade Federal do Piauí/Centro de Ciências Agrárias. Teresina, PI, Brasil. E-mail: solangeufrpe@yahoo.com.br (Corresponding author) - ORCID: \\ 0000-0001-7602-6635 \\ ${ }^{3}$ Universidade Federal de Pernambuco/Departamento de Química Fundamental. Recife, PE, Brasil. E-mail: navarrix@uol.com.br - ORCID: 0000-0003- \\ 0158-7221; kamilladutra_kd@hotmail.com - ORCID: 0000-0002-8789-4603
}

\begin{abstract}
This study had the following objectives: to identify and quantify the constituent compounds of essential oils from Cymbopogon winterianus Jowitt, Eucalyptus globulus Labill., Eucalyptus staigeriana F. Muell. ex F.M. Bailey, Foeniculum vulgare Mill., Ocimum basilicum L., Ocimum gratissimum L., and Piper hispidinervum C. DC., investigate their toxicity and repellency to $S$. zeamais and evaluate the toxicity of $P$. hispidinervum to immature S. zeamais. Individual tests for each essential oil were conducted with a completely randomized design with five concentrations for each oil and four replicates. Gas chromatography-mass spectrometry revealed the presence of citronellal in C. winterianus, 1,8-cineole in E. globulus, limonene in E. staigeriana, limonene in F. vulgare, linalool in O. basilicum, (E)-anethole in O. gratissimum, and safrole in $P$. hispidinervum. The median lethal concentration required to kill $50 \%$ of the insect $\left(\mathrm{LC}_{50}\right)$ in contact

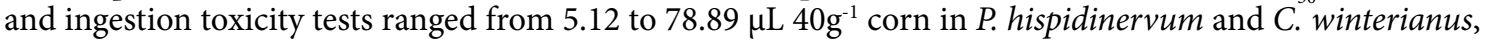
respectively. In adult fumigation tests, the $\mathrm{LC}_{50}$ ranged from 2.1 to $19.4 \mu \mathrm{L} \mathrm{L}^{-1}$ air, and in immature fumigation tests, the egg stage was susceptible to essential oil, whereas larval and pupal phases were tolerant. All of the oils repelled $S$. zeamais.
\end{abstract}

Key words: alternative fumigant, bioactivity, lethal concentration, maize weevil, natural insecticide

\section{Toxicidade e repelência de óleos essenciais no manejo de Sitophilus zeamais}

RESUMO: Este trabalho teve os seguintes objetivos: identificar e quantificar os compostos constituintes dos óleos essenciais de Cymbopogon winterianus Jowitt, Eucalyptus globulus Labill., Eucalyptus staigeriana F. Muell. ex F.M. Bailey, Foeniculum vulgare Mill., Ocimum basilicum L., Ocimum gratissimum L., e Piper hispidinervum C. DC., investigar suas toxicidades e repelências a $S$. zeamais e avaliar a toxicidade de $P$. hispidinervum a $S$. zeamais imaturos. Testes de indivíduos para cada óleo essencial foram conduzidos em delineamento experimental inteiramente casualizado com cinco concentrações para cada óleo essencial e quarto repetições. A análise dos óleos por cromatografia gasosa e espectrometria de massa revelou a presença majoritária de Citronelal para C. winterianus; 1,8-Cineole para E. globulus; Limoneno para E. staigeriana; Limoneno para F. vulgare; Linalol para O. basilicum; (E)-Anethole para O. gratissimum e Safrole para $P$. hispidinervum. Nos testes de toxicidade por contato e ingestão, obteve-se uma $\mathrm{CL}_{50}$ variando de 5,12 a 78,89 $\mu \mathrm{L} 40 \mathrm{~g}^{-1}$ de milho, em $P$. hispidinervum e C. winterianus, respectivamente. Nos testes de fumigação para adultos, as $\mathrm{CL}_{50}$ variaram de 2,1 a 19,4 $\mu \mathrm{L} \mathrm{L}^{-1}$ de ar. Nos testes de fumigação de imaturos, o estágio de ovo foi suscetível ao óleo essencial, enquanto que as fases de larva e pupa mostraram-se tolerantes. Todos os óleos foram repelentes para $S$. zeamais.

Palavras-chave: fumigantes alternativos, bioatividade, concentração letal, gorgulho do milho, inseticidas naturais 


\section{INTRODUCTION}

Cereal output for 2015 was estimated at a record level of 107 million tons, and corn (Zea mays) accounted for $79 \%$ of it (FAO, 2015). In Brazil, about $17 \%$ of the whole grain yield is lost to pests (Antunes et al., 2011), and the maize weevil Sitophilus zeamais Mots. (Coleoptera: Curculionidae) is the main pest of stored grains and processed products. This insect has a high biotic potential and a large number of hosts, exhibits cross-infestation, and easily penetrates grain (Lorini, 2002).

The use of synthetic insecticides has raised concerns related to the environment and human health (Nerio et al., 2010), and promising alternatives include inert powders such as diatomaceous earth as well as modified atmosphere packaging and essential oils (Araújo et al., 2016; Malia et al., 2016; Sousa et al., 2017). A large number of plant substances have physiological and behavioral effects on stored-product pests, and are being used as alternatives to synthetic insecticides (Rajedran \& Sriranjini, 2008).

Essential oils and extracts from the following plants may be effective in controlling S. zeamais: Citrus bergamia Risso and Poit., Lavandula hybrida Rev. (Cosimi et al., 2009; Li et al., 2013), Lippia alba (Mill.) N.E. Brown, Tagetes lucida Cav., Rosmarinus officinalis L., Cananga odorata (Lam.) Hook.f. \& Thomson, Eucalyptus citriodora Hook., and Cymbopogon citratus (DC.) Stapf. (Nerio et al., 2010).

This study had the following objectives: to identify and quantify the constituent compounds of essential oils from Cymbopogon winterianus Jowitt, Eucalyptus globulus Labill., Eucalyptus staigeriana F. Muell. ex F.M. Bailey, Foeniculum vulgare Mill., Ocimum basilicum L., Ocimum gratissimum L., and Piper hispidinervum C. DC., investigate their toxicity and repellency to $S$. zeamais, and evaluate the toxicity of $P$. hispidinervum to immature S. zeamais.

\section{Material AND Methods}

S. zeamais were reared on 'Caatingueiro' corn seeds that were obtained from Embrapa Semiárido, Petrolina, Pernambuco State, Brazil. They were maintained at $27 \pm 3{ }^{\circ} \mathrm{C}$ with a relative humidity of $65 \pm 5 \%$ and a photoperiod of $12 \mathrm{~h}$ in glass containers that were sealed with perforated plastic lids and internally coated with an organdy mesh screen to allow gas exchange. The insects were left for 15 days to lay their eggs ( $\mathrm{F}_{1}$ generation) in the grain mass before being removed. This procedure was conducted for successive generations in order to obtain the required number of adults needed to perform the experiments.

The $P$. hispidinervum essential oil was obtained from Embrapa (Acre), those from O. basilicum and E. globulus were obtained from Quinarí Casa das Essências (Ponta Grossa, Paraná State), that from E. staigeriana was obtained from the Departamento de Ciência Florestal- Escola Superior de Agricultura Luiz de Queiroz (ESALQ-USP), and those from F. vulgare, C. winterianus, and O. gratissimum were obtained from the Universidade Federal da Paraíba, Campus Bananeiras.

Qualitative analyses of each essential oil were conducted using an Agilent 5975C Series Gas Chromatograph/Mass Selective Detector (Agilent Technologies, Palo Alto, CA, USA) equipped with a DB-5 column (Agilent J\&W; $30 \times 0.25-\mathrm{mm}$ inner diameter, $0.25-\mu \mathrm{m}$ film thickness). A $1-\mu \mathrm{L}$ aliquot of essential oil solution of known concentration and a solution of hydrocarbons pattern mixed (C9-C34) were injected in split mode (1:20). The hexane solution was comprised of commercial patterns from Sigma-Aldrich: The temperature of the gas chromatograph oven was set at $60{ }^{\circ} \mathrm{C}$ for $3 \mathrm{~min}$, and was then increased by $4{ }^{\circ} \mathrm{C} \mathrm{min}^{-1}$ up to $240{ }^{\circ} \mathrm{C}$, which was maintained for $10 \mathrm{~min}$. The helium flow was kept at a constant pressure of $100 \mathrm{kPa}$. The mass spectrometer interface temperature was set at $200{ }^{\circ} \mathrm{C}$, and the mass spectra of the compounds were recorded at $70 \mathrm{eV}$ (EI mode) with a scanning speed of $0.5 \mathrm{scan}^{-\mathrm{s}}$ of $\mathrm{m} / \mathrm{z} 20-350$.

Retention indices (RI) of each compound in the essential oils were calculated based on the retention times of pattern hydrocarbons and of a solution of the essential oils mixed with the hydrocarbons using the van den Dool and Kratz equation. Essential oil compounds were identified by comparing the retention indices obtained with those available in the literature, and confirmed by comparing their mass spectra with those stored in MassFinder 4, NIST08, and the Wiley Registry" (9th Edition), and with other mass spectra data published by Adams (2007). Finally, areas of integrated peaks in the chromatograms were obtained using an Agilent MSD Productivity ChemStation to ascertain the relative proportion of each compound.

The corn seeds were placed in plastic bags and stored in a freezer at $-10{ }^{\circ} \mathrm{C}$ to eliminate any infestation of insects from the field. After removal from the freezer, they were transferred to glass jars and kept in the laboratory at room temperature for 15 days.

Contact and ingestion toxicity tests in adult $S$. zeamais were conducted at $27 \pm 3{ }^{\circ} \mathrm{C}$ with a relative humidity of $65 \pm 5 \%$ and a photoperiod of 12:12 h (L:D). The following essential oil volumes were applied in each treatment to $40 \mathrm{~g}$ of corn grains: C. winterianus $(40,50.4,70,80,100$, and $110 \mu \mathrm{L})$, E. globulus $(30,32.4,35,37.8,40.8$, and $45 \mu \mathrm{L})$, E. staigeriana (40, 48.8, $59.5,80$, and $90 \mu \mathrm{L}), F$. vulgare $(20,23.4,27.4,32$, and $43 \mu \mathrm{L})$, O. basilicum $(18,21,24.7,29,33.8$, and $40 \mu \mathrm{L})$, O. gratissimum $(35,41.7,54.3,59$, and $70 \mu \mathrm{L})$, and P. hispidinervum $(3,3.75$, $4.7,5.9,7.3$, and $9 \mu \mathrm{L})$. The latter was used as a positive control after Coitinho et al. (2011), who estimated the median lethal concentration required to kill $50 \%$ of the individuals $\left(\mathrm{LC}_{50}\right)$ as $1 \mu \mathrm{L} 40 \mathrm{~g}^{-1}$ corn. Concentrations were estimated during preliminary tests that yielded mortalities of between 5 and 95\% in order to establish the final concentrations (Finney, 1971). The essential oils were applied to the corn seeds using an automatic pipettor inside glass containers, which were manually shaken for $2 \mathrm{~min}$. Each $40 \mathrm{~g}$ corn sample was infested with 16 adult $S$. zeamais of indeterminate sex that were 0 -15 days old. After $48 \mathrm{~h}$ of confinement, mortality percentages were determined.

Individual tests for each essential oil were conducted with a completely randomized design with five concentrations for each oil and four replicates. The $\mathrm{LC}_{50}$ was estimated using the computer program POLO-PC (LeOra Software, 1987). The toxicity ratio (TR) was obtained from the quotient between the $\mathrm{LC}_{50}$ of the essential oil that had the lowest toxicity and the $\mathrm{LC}_{50}$ values of the other oils. 
Fumigant tests on adults were conducted at $27 \pm 3{ }^{\circ} \mathrm{C}$ with a relative humidity of $65 \pm 5 \%$ and a photoperiod of $12: 12 \mathrm{~h}$ (L:D) according to the methodology adapted from Aslan et al. (2004). Glass containers (2.5-L capacity) were used as fumigation chambers in which 20 unsexed adult $S$. zeamais ( $0-15$ days old) were placed with $40 \mathrm{~g}$ of corn. The following concentrations were used in the treatments: E. globulus $(14,16.1,18.5,21.3,24.5$, and $28 \mu \mathrm{L} \mathrm{L}^{-1}$ air), F. vulgare $\left(4,6.9,11.8,20.4,35\right.$, and $60 \mu \mathrm{L} \mathrm{L}^{-1}$ air), O. basilicum $\left(8,10,12.5,15.6,19.5\right.$, and $24 \mu \mathrm{L} \mathrm{L}^{-1}$ air), and $P$. hispidinervum $\left(1.4,1.68,2.04,3\right.$, and $3.6 \mu \mathrm{L} \mathrm{L}^{-1}$ air $)$ as a positive control because its fumigant activity has already been studied, with an estimated $\mathrm{LC}_{50}$ of $0.53 \mu \mathrm{L} \mathrm{L}^{-1}$ air (Coitinho et al., 2011). The oils were applied using an automatic pipettor on $18-\mathrm{cm}^{2}$ filter paper that was fixed to the lower surface of the container lid. To avoid direct contact of the oil on the insects, an organdy mesh screen was placed between the lid and the container, where the filter paper was placed. For complete sealing, the containers were wrapped in plastic wrap and tape. Individual tests were performed for each essential oil with a completely randomized design and a minimum of five treatments and four replicates, and mortality was evaluated $48 \mathrm{~h}$ after essential-oil exposure.

Repellency tests were performed in arenas composed of two plastic containers connected by two plastic tubes to a central box. In one of the containers, $20 \mathrm{~g}$ of corn grains without oil (control) were placed, and in the other, the same amount of grains that had been impregnated with the oil under test was placed. Sixteen unsexed adult $S$. zeamais aged $0-15$ days were released into the central box, and each oil was tested with a completely randomized design with two treatments (oil and control) and 10 replicates. After $48 \mathrm{~h}$, insects in each container were counted to evaluate the repellent effect. Data were subjected to an analysis of frequency of choice using the Proc Freq procedure in SAS (SAS Institute, 2002) and interpreted by the chi-square test at 0.05 probability. The percentage of repellency was calculated according to the following formula: $\mathrm{PR}=[(\mathrm{NC}-\mathrm{NT}) /(\mathrm{NC}+\mathrm{NT}) \times 100]$, where $\mathrm{PR}$ is the percentage of repellency, $\mathrm{NC}$ is the number of insects in the control treatment, and NT is the number of insects in the experimental treatment (Obeng-Ofori \& Amiteye, 2005).

For fumigant tests on immature S. zeamais, $30 \mathrm{~g}$ of untreated corn grains were infested with 50 adult insects in glass containers for oviposition for six days. As immature stages occur inside grains, the samples were infested with eggs, third instar larvae, and pupae at 0, 18, and 30 days after the oviposition period (Paes et al., 2012).

Corn grains containing eggs, larvae, and pupae were exposed to the essential oil from $P$. hispidinervum at a concentration of $2.1 \mu \mathrm{L} \mathrm{L}^{-1}$ air for 10 periods of exposure (6, $12,18,24,30,36,42,48,54$ and $60 \mathrm{~h}$ ) with four replicates. This concentration was determined in previous tests on adults. For the control, the test was performed under the same conditions as described above with grains containing immature stages, but they were not exposed to the essential oil.

Experiments were performed in 2.5-L glass containers containing corn grains. The essential oil was applied using an automatic pipettor on $18-\mathrm{cm}^{2}$ filter paper that was fixed to the lower surface of the container lid. The containers were wrapped in plastic wrap and tape.

At the end of each exposure period, the corn grains were removed and placed in smaller glasses. The effect of the essential oil from $P$. hispidinervum on immature insects was determined at 42 days after the laying date by counting the number of adults that emerged. Data were analysed using the PROC REG procedure in SAS (SAS Institute, 2002).

\section{Results AND Discussion}

The main components of the oils were citronellal (35.47\%; $\mathrm{RI}=1154)$, geraniol $(21.83 \%$; RI $=1256)$, and citronellol $(10.94 \%$; RI $=1229)$ in C. winterianus; 1.8 -cineole $(89.97 \%$; $\mathrm{RI}=1032)$ in E. globulus; limonene $(28.73 \%$; RI = 1029), geranial $(15.20 \%$; RI $=1272)$, and neral $(12.16 \%$; RI $=1242)$ in E. staigeriana; limonene (41.82\%; RI = 1029), (E)-anethole $(17.91 \%$; RI $=1290)$, and $\alpha$-pinene $(11.13 \%$; $\mathrm{RI}=932)$ in $F$. vulgare; linalool $(62.47 \%$; RI $=1107)$ and methyl chavicol $(30.94 \%$; RI $=1204)$ in O. basilicum; $(\mathrm{E})$-anethole $(34.95 \%$; $\mathrm{RI}=1286)$, limonene $(15.63 \%$; RI = 1028), and eugenol $(9.07 \%$; $\mathrm{RI}=1358)$ in O. gratissimum; and safrole $(82.07 \%$; RI $=1289)$ in $P$. hispidinervum.

According to the $\mathrm{LC}_{50}$ values, the contact and ingestion toxicities of the essential oils to adult $S$. zeamais decreased in the following order: P. hispidinervum $>$ F. vulgare $>O$. basilicum $>$ E. globulus $>$ O. gratissimum $>$ E. staigeriana with TRs of 15.4, 2.94, 2.93, 2.08, 1.66, and 1.27, respectively, relative to C. winterianus oil (Table 1). P. hispidinervum oil was the most effective, with the highest TR (Table 2). Coitinho et al. (2011) reported that $P$. hispidinervum was toxic to $S$. zeamais

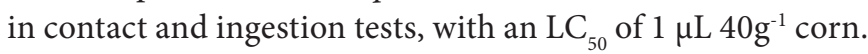
Nguemtchouin et al. (2013) reported a mortality rate of up to $100 \%$ for S. zeamais in contact with O. gratissimum oil diluted in acetone.

The toxicity of the essential oils and their chemical components by contact and ingestion indicates that many of them are effective, and can be used as an alternative to chemical insecticides for controlling many pests of stored grains (Gusmão

Table 1. Contact and ingestion toxicities of essential oils to adult Sitophilus zeamais

\begin{tabular}{|c|c|c|c|c|c|}
\hline Treatment & $\mathbf{N}$ & Slope \pm SE & $\mathrm{LC}_{50}(\mathrm{Cl} 95 \%) \mu \mathrm{L} 40 \mathrm{~g}^{-1}$ & $\mathrm{TR}_{50}$ & $x^{2}$ \\
\hline Piper hispidinervum & 448 & $8.03 \pm 0.65$ & $5.12(4.88-5.36)$ & 15.40 & 2.27 \\
\hline Foeniculum vulgare & 384 & $8.43 \pm 0.87$ & 26.78 (24.63-29.04) & 2.94 & 3.56 \\
\hline Ocimum basilicum & 448 & $9.97 \pm 0.83$ & 26.90 (25.47-28.43) & 2.93 & 4.37 \\
\hline Eucalyptus globulus & 448 & $20.13 \pm 1.69$ & 37.88 (36.68-39.21) & 2.08 & 6.13 \\
\hline Ocimum gratissimum & 384 & $9.43 \pm 0.87$ & 47.47 (45.48-49.42) & 1.66 & 2.70 \\
\hline Eucalyptus staigeriana & 384 & $9.78 \pm 0.83$ & 61.73 (57.22-66.70) & 1.27 & 3.44 \\
\hline Cymbopogon winterianus & 448 & $7.43 \pm 0.67$ & 78.89 (73.25-84.86) & - & 4.43 \\
\hline
\end{tabular}

$\mathrm{N}$ - Number of insects; SE - Standard error; $\mathrm{LC}_{50}$ - Median lethal concentration required to kill $50 \%$ of the individuals; CI - Confidence interval; TR - Toxicity ratio; $\chi^{2}$ - Chi-square; ${ }^{*}$ Positive control 
et al., 2013). An essential oil from Chenopodium ambrosioides L. and its constituents ascaridole and isoascaridole had $\mathrm{LC}_{50}$ values of only $2.12,0.86$, and $2.16 \mu \mathrm{g} \mathrm{g}^{-1}$ insect weight, respectively, in adult $S$. zeamais (Chu et al., 2011).

The fumigant toxicity of the essential oils decreased in the following order: P. hispidinervum $>$ O. basilicum $>$ F. vulgare $>$ E. globulus, with $\mathrm{LC}_{50}$ values ranging from 2.1 to $19.4 \mu \mathrm{L} \mathrm{L}^{-1}$ air. E. globulus oil had the highest $\mathrm{LC}_{50}$ (Table 2). The TRs were 9.23, 1.39, and 1.22 for P. hispidinervum, O. basilicum, and $F$. vulgare, respectively, relative to E. globulus. Piper hispidinervum was a positive control and had the lowest $\mathrm{LC}_{50}$, which was significantly different to those of the other oils according to its confidence intervals (Table 2). Coitinho et al. (2011) attributed the high toxicity of $P$. hispidinervum to its volatile oil and the presence of safrole, its main compound. In this study, in five of the oils tested, it was possible to confirm the presence of limonene by its composition, and was one of the main compounds in E. staigeriana, F. vulgare, and O. gratissimum oils. Restello et al. (2009) reported a mortality rate of up to $100 \%$ of adult S. zeamais when fumigated with Tagetes patula oil, which contains limonene.

The insecticidal activity of 1.8 -cineole, which is a major constituent of E. globulus oil, has been proven against Tribolium castaneum (H.) (Stamopoulos et al., 2007), Sitophilus oryzae (L.), Oryzaephilus surinamensis (L.), and S. zeamais (Lee et al., 2003).

All of the essential oils were significantly more repellent to adult $S$. zeamais than their respective controls $(\mathrm{p}<0.0001)$ (Figure 1). The mean repellency percentages were as follows: E. staigeriana (96.25\%), O. basilicum (91.19\%), O. gratissimum (90\%), C. winterianus (81.82\%), E. globulus (79.62\%), F. vulgare (77.07\%), and P. hispidinervum (49.37\%). The highest repellency was observed in E. staigeriana, but O. basilicum, $O$. gratissimum, C. winterianus, E. globulus, and F. vulgare also had repellencies higher than 70\% (Figure 1). Nerio et al. (2010), in a recent review of the repellent effect of essential oils to Diptera, stated that the most important oils that have been tested are from Cymbopogon spp., Ocimum spp., and Eucalyptus spp., similar to the results obtained in this study for S. zeamais.

The repellent effect of Cymbopogon spp. has been attributed to the presence of volatile substances in its leaves, such as citronellal, citronellol, and geraniol, among others (Shasany et al., 2000). Essential oils from Eucalyptus benthamii Maid. \& Camb., Eucalyptus dunnii Maiden, E. globulus, Eucalyptus viminalis Labill., and Eucalyptus saligna Smith are also repellent to S. zeamais (Mossi et al., 2010). Similarly, hexane extracts from Eucalyptus camaldulensis Schlecht and E. citriodora oil had 74.35 and $69.15 \%$ repellency, respectively, when used at a concentration of $2 \mu \mathrm{L} \mathrm{LL}^{-1}$ (Karemu et al., 2013). Other essential oils have also shown promising results as repellents against $S$. zeamais, such as Lippia origanoides Kunth, E. citriodora, and $T$. lucida collected in Colombia, with 92, 91, and 79\% repellencies,

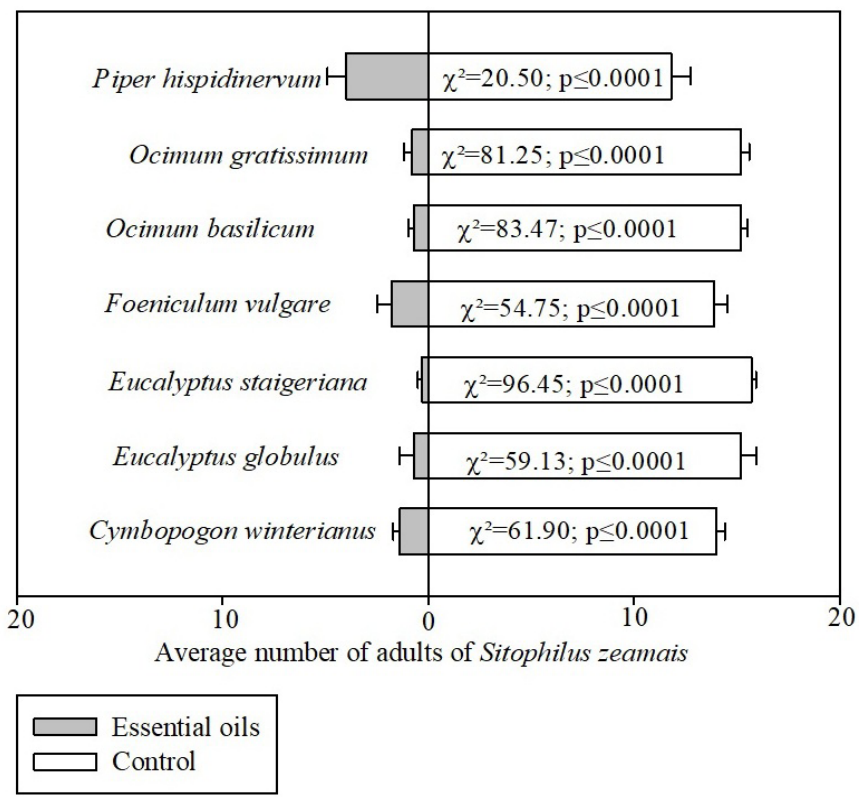

Figure 1. A verage number of Sitophilus zeamais adults in each treatment and their respective controls in repellence tests

respectively, in concentrations between 0.063 and $0.503 \mu \mathrm{L} \mathrm{cm}^{-2}$ (Nerio et al., 2009). Oils from C. bergamia and L. hybrida are also effective against $S$. zeamais, with average repellencies of 56.3 and $50 \%$, respectively, in a dilution of $0.1 \%$ of the oils in ether (Cosimi et al., 2009).

The number of adults that emerged from corn grains infested with eggs exposed to $P$. hispidinervum oil was lower than the control at all timepoints. A quadratic regression model was the best fit to the data, which estimated the timepoint of minimum emergence as $41.31 \mathrm{~h}$ of exposure to the essential oil (Figure 2). In contrast, the data obtained for the developmental

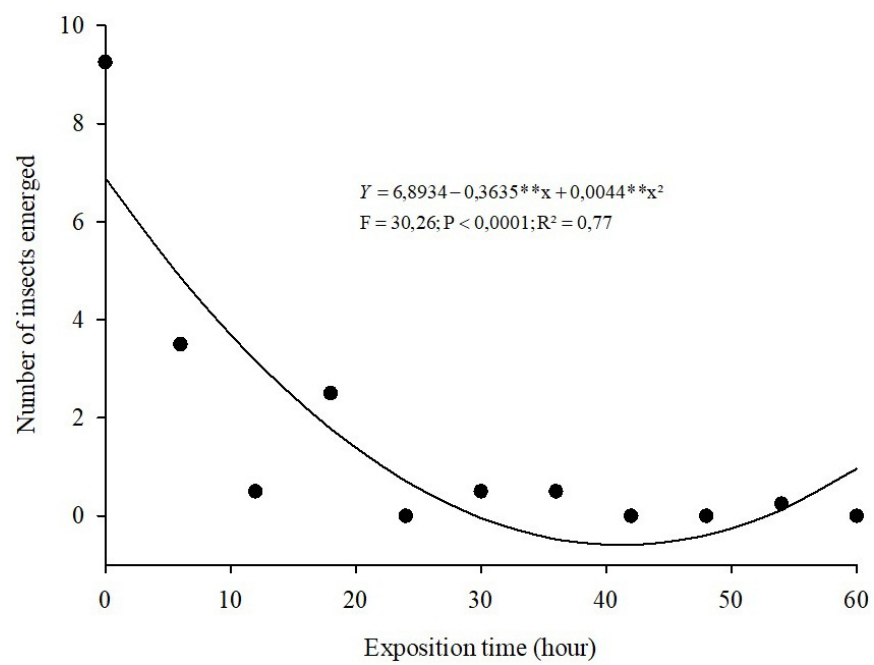

Figure 2. Number of Sitophilus zeamais adults that emerged from 'Caatingueiro' seeds treated with Piper hispidinervum essential oil during the egg stage

Table 2. Fumigant toxicity of essential oils to adult Sitophilus zeamais

\begin{tabular}{|c|c|c|c|c|c|}
\hline Treatment & $\mathbf{N}$ & Slope \pm SE & $\mathrm{LC}_{50}(\mathrm{Cl} 95 \%) \mu \mathrm{L} 40 \mathrm{~g}^{-1}$ & $\mathrm{TR}_{50}$ & $x^{2}$ \\
\hline Piper hispidinervum* & 560 & $6.44 \pm 0.53$ & $2.1(1.94-2.26)$ & 9.23 & 4.8 \\
\hline Ocimum basilicum & 560 & $5.78 \pm 0.46$ & $13.9(13.2-14.6)$ & 1.39 & 3.0 \\
\hline Foeniculum vulgare & 480 & $3.08 \pm 0.23$ & $15.8(12.2-19.9)$ & 1.22 & 4.0 \\
\hline Eucalyptus globulus & 560 & $10.8 \pm 0.82$ & 19.4 (18.3-20.2) & - & 7.5 \\
\hline
\end{tabular}

$\mathrm{N}$ - Number of insects; SE - Standard error; $\mathrm{LC}_{50}$ - Median lethal concentration required to kill $50 \%$ of the individuals; CI - Confidence interval; TR - Toxicity ratio; $\chi^{2}$ - Chi-square; ${ }^{\star}$ Positive control 
stages did not fit any regression model tested, and the average larval $(\mathrm{F}=0.12 ; \mathrm{P}=0.7317)$ and pupal $(\mathrm{F}=0.41 ; \mathrm{P}=0.5268)$ developmental times did not significantly differ.

The median lethal times (time until death) to kill 50\% $\left(\mathrm{LT}_{50}\right)$ and $95 \%\left(\mathrm{LT}_{95}\right)$ of the eggs were 16.72 and $77.77 \mathrm{~h}$, respectively, at a concentration of $1.25 \mu \mathrm{L} \mathrm{L}^{-1}$, and 16.52 and $60.86 \mathrm{~h}$, respectively, at a concentration of $1.87 \mu \mathrm{L} \mathrm{L}^{-1}$. Paes et al. (2012) tested two concentrations of mustard essential oil on immature S. zeamais at different stages of development and found that eggs were more tolerant than pupae and larvae.

In contrast, in study, there was a significant reduction in adult emergence when eggs were exposed to essential oils, showing that this stage was the most susceptible. Santos et al. (2011) tested allyl isothiocyanate, which is the main constituent of the mustard essential oil, as a fumigant against immature stages in two populations of T. castaneum, and reported a low $\mathrm{LC}_{50}$ for the egg stage. The susceptibility of stored products to insect eggs may vary depending upon the insect species in question and the essential oil tested (Rajendran \& Sriranjini, 2008).

Extracts of Nicotiana tabacum L. and C. citratus leaves have fumigant effects on immature stages of $S$. zeamais, and reduce adult emergence by 96.55 and $95.07 \%$, respectively (Almeida et al., 2005). Nukenine et al. (2010) studied two populations of $S$. zeamais, and reported that both had a $100 \%$ reduction in adult emergence after being exposed to an essential oil from Plectranthus glandulosus Hook f. at a concentration of $20 \mu \mathrm{L} 40 \mathrm{~g}^{-1}$ corn.

The effects of contact, ingestion, and fumigation, allied to rapid degradation in the environment and the safety and efficacy of their application, suggest that essential oils are an effective alternative for the management of adult and immature stages of S. zeamais, particularly the essential oil from $P$. hispidinervum.

\section{Conclusions}

1. The essential oils of Foeniculum vulgare and Ocimum basilicum are more toxic at lower concentrations and, therefore, the most promising, via not only fumigation, but contact and ingestion, for the control of Sitophilus zeamais in stored corn (Zea mays).

2. All essential oils tested are repellent to S. zeamais in corn.

3. The oil of $P$. hispidinervum reduced the number of emerged adults from corn grains previously infested with $S$. zeamais, indicating a curative effect of this oil.

\section{Acknowledgments}

We thank the Conselho Nacional de Desenvolvimento Científico e Tecnológico (CNPq, Brazil) for providing a scholarship to the first author and research funding.

\section{Literature Cited}

Adams, R. P. Identification of essential oil components by chromatography/mass spectrometry. Carol Stream: Allured Publishing Corporation, 2007. 804p.
Almeida, F. de A. C.; Pessoa, E. B.; Gomes, J. P.; Silva, A. S. Emprego de extratos vegetais no controle das fases imatura e adulta do Sitophilus zeamais. Agropecuária Técnica, v.26, p.46-53, 2005.

Antunes, L. E. G.; Viebrantz, P. C.; Gottardi, R.; Dionello, R. G. Características físico-químicas de grãos de milho atacados por Sitophilus zeamais durante o armazenamento. Revista Brasileira de Engenharia Agrícola e Ambiental, v.15, p.615-620, 2011. https:// doi.org/10.1590/S1415-43662011000600012

Araújo, A. M. N. de; Faroni, L. R. A.; Oliveira, J. V. de; Navarro, D. M. do A. F.; Barbosa, D. R. e S.; Breda, M. O.; França, S. M. de. Lethal and sublethal responses of Sitophilus zeamais populations to essential oils. Journal of Pest Science, v.90, p.589-600, 2016. https://doi.org/10.1007/s10340-016-0822-z

Aslan, İ.; Özbek, H.; Çalmasur, Ö.; Şahin, F. Toxicity of essential oil vapours to two greenhouse pests, Tetranychus urticae Koch and Bemisia tabaci Genn. Industrial Crops and Products, v.19, p.167173, 2004. https://doi.org/10.1016/j.indcrop.2003.09.003

Chu, S. S.; Hu, J. F.; Liu, Z. L. Composition of essential oil of Chinese Chenopodium ambrosioides and insecticidal activity against maize weevil, Sitophilus zeamais. Pest Management Science, v.67, p.714718, 2011. https://doi.org/10.1002/ps.2112

Coitinho, R. L. B. de C.; Oliveira, J. V. de; Gondim Junior, M. G. C.; Câmara, C. A. G. da. Toxicidade por fumigação, contato e ingestão de óleos essenciais para Sitophilus zeamais Motschulsky, 1885 (Coleoptera: Curculionidae). Ciência e Agrotecnologia, v.35, p.172-178, 2011. https://doi.org/10.1590/ S1413-70542011000100022

Cosimi, S.; Rossi, E.; Cioni, P. L.; Canale, A. Bioactivity and qualitative analysis of some essential oils from Mediterranean plants against stored-product pests: Evaluation of repellency against Sitophilus zeamais Motschulsky, Cryptolestes ferrugineus (Stephens) and Tenebrio molitor (L.). Journal of Stored Products Research, v.45, p.125-132, 2009. https://doi.org/10.1016/j.jspr.2008.10.002

FAO - Food and Agriculture Organization of the United Nations. 2015. Available on: <http://www.fao.org/countryprofiles/index/ en/?iso3=BRA $>$. Accessed on: Mar. 2016.

Finney, D. J. Probit analysis. 3.ed. London: Cambridge Press, 1971. $338 \mathrm{p}$.

Gusmão, N. M. S.; Oliveira, J. V. de; Navarro, D. M. do A. F.; Dutra, K. A.; Silva, W. A. da; Wanderley, M. J. A. Contact and fumigant toxicity and repellency of Eucalyptus citriodora Hook., Eucalyptus staigeriana F., Cymbopogon winterianus Jowitt and Foeniculum vulgare Mill. essential oils in the management of Callosobruchus maculatus (Fabr.) (Coleoptera: Chrysomelidae, Bruchinae). Journal of Stored Products Research, v.54, p.41-47, 2013. https:// doi.org/10.1016/j.jspr.2013.02.002

Karemu, C. K.; Ndung'u, M. W.; Githua, M. Repellent effects of essential oils from selected eucalyptus species and their major constituents against Sitophilus zeamais (Coleoptera: Curculionidae). International Journal of Tropical Insect Science, v.33, p.188-194, 2013. https://doi.org/10.1017/S1742758413000179

Lee, S.; Peterson, C. J.; Coats, J. R. Fumigation toxicity of monoterpenoids to several stored product insects. Journal of Stored Products Research, v.39, p.77-85, 2003. https://doi. org/10.1016/S0022-474X(02)00020-6

LeOra Software. POLO-PC: A user's guide to probit or logit analysis. Berkeley: LeOra Software, 1987. sp. 
Li, S. G.; Li, M. Y.; Huang, Y. Z.; Hua, R. M.; Lin, H. F.; He, Y. J.; Wei, L. L.; Liu, Z. Q. Fumigant activity of Illicium verum fruit extracts and their effects on the acetylcholinesterase and glutathione S-transferase activities in adult Sitophilus zeamais. Journal of Pest Science, v.86, p.677-683, 2013. https://doi.org/10.1007/ s10340-013-0520-z

Lorini, I. Descrição, biologia e danos das principais pragas de grãos armazenados. In: Lorini, I.; Milke, L. H.; Scussel, V. M. (eds.). Armazenagem de grãos. Campinas: Instituto Bio Geneziz, 2002. p.381-397.

Malia, H. A. E.; Rosi-Denadai, C. A.; Guedes, N. M. P.; Martins, G. F.; Guedes, R. N. C. Diatomaceous earth impairment of water balance in the maize weevil, Sitophilus zeamais. Journal of Pest Science, v.89, p.945-954, 2016. https://doi.org/10.1007/s10340-016-0732-0

Mossi, A. J.; Astolfi, V.; Kubiak, G.; Lerin, L.; Zanella, C.; Toniazzo, G.; Oliveira, D.; Treichel, H.; Devilla, I. A.; Cansian, R.; Restello, R. Insecticidal and repellency activity of essential oil of Eucalyptus sp. against Sitophilus zeamais Motschulsky (Coleoptera, Curculionidae). Journal of the Science of Food and Agriculture, v.91, p.273-277, 2010. https://doi.org/10.1002/jsfa.4181

Nerio, L. S.; Oliveiro-Verbel, J.; Stashenko, E. E. Repellent activity of essential oils from seven aromatic plants grown in Colombia against Sitophilus zeamais Motschulsky (Coleoptera). Journal of Stored Products Research, v.45, p.212-214, 2009. https://doi. org/10.1016/j.jspr.2009.01.002

Nerio, L. S.; Oliveiro-Verbel, J.; Stashenko, E. E. Repellent activity of essencial oils: A review. Bioresource Technology, v.101, p.372-378, 2010. https://doi.org/10.1016/j.biortech.2009.07.048

Nguemtchouin, M. G. M.; Ngassoum, M. B.; Chalier, P.; Kamga, R.; Ngamo, L. S. T.; Cretin, M. Ocimum gratissimum essential oil and modified montmorillonite clay, a means of controlling insect pests in stored products. Journal of Stored Products Research, v.52, p.57-62, 2013. https://doi.org/10.1016/j.jspr.2012.09.006

Nukenine, E. N.; Adler, C.; Reichmuth, C. Bioactivity of fenchone and Plectranthus glandulosus oil against Prostephanus truncates and two strains of Sitophilus zeamais. Journal of Applied Entomology, v.134, v.132-141, 2010.
Obeng-Ofori, D.; Amiteye, S. Efficacy of mixing vegetable oils with pirimiphos-methyl against the maize weevil, Sitophilus zeamais Motschulsky in stored maize. Journal of Stored Products Research, v.41, p.57-66, 2005. https://doi.org/10.1016/j.jspr.2003.11.001

Paes, J. L.; Faroni, L. R. A.; Dhingra, O. D.; Cecon, P. R.; Silva, T. A. Insecticidal fumigant action of mustard essential oil against Sitophilus zeamais in maize grains. Crop Protection, v.34, p.56-58, 2012. https://doi.org/10.1016/j.cropro.2011.11.021

Rajendran, S.; Sriranjini, V. Plants products as fumigants for storedproducts insect control. Journal of Stored Products Research, v.44, p.126-135, 2008. https://doi.org/10.1016/j.jspr.2007.08.003

Restello, R. M.; Menegatt, C.; Mossi, A. J. Efeito do óleo essencial de Tagetes patula L. (Asteraceae) sobre Sitophilus zeamais Motschulsky (Coleoptera: Curculionidae). Revista Brasileira de Entomologia, v.53, p.304-307, 2009. https://doi.org/10.1590/ S0085-56262009000200015

Santos, J. C.; Faroni, L. R. A.; Sousa, A. H.; Guedes, R. N. C. Fumigant toxicity of allyl isothiocyanate to populations of the red flour beetle Tribolium castaneum. Journal of Stored Products Research, v.47, p.238-243, 2011. https://doi.org/10.1016/j.jspr.2011.03.004 SAS - Statistical Analysis System. Version 8.02 - TS level 2MO Output delivery system: User's guide. Cary: SAS Institute, 2002. 943p.

Shasany, A. K.; Lal, R. K.; Patra, N. K.; Darokar, M. P.; Garg, A.; Kumar, S.; Khanuja, S. P. S. Phenotypic and RAPD diversity among Cymbopogon winterianus Jowitt accessions in relation to Cymbopogon nardus Rendle. Genetic Resources and Crop Evolution, v.47, p.553-559, 2000. https://doi. org/10.1023/A:1008712604390

Sousa, A. H.; Faroni, L. R. A.; Guedes, R. N. C. Locomotor behavior of Sitophilus zeamais populations under sublethal ozone exposure. Journal of Pest Science, v.90, p.239-247, 2017. https://doi. org/10.1007/s10340-016-0738-7

Stamopoulos, D. C.; Damos, P.; Karagianidou, G. Bioactivity of five monoterpenoid vapours to Tribolium confusum (du Val) (Coleoptera: Tenebrionidae). Journal of Stored Products Research, v.43, p.571-577, 2007. https://doi.org/10.1016/j.jspr.2007.03.007 